\title{
UJI AKTIVITAS ANTIBAKTERI SEDIAAN SABUN CAIR EKSTRAK DAUN MENGKUDU (Morinda citrifolia L.) TERHADAP STAPHYLOCOCCUS AUREUS
}

\author{
Fajrin Noviyanto ${ }^{*}$, Siti Nuriyah ${ }^{2}$, Hadi Susilo ${ }^{3}$ \\ ${ }^{1}$ Jurusan Farmasi, Fakultas Farmasi, Stikes Salsabila Serang, \\ Jl. Raya Serang-Pandeglang No.33 42171 Kota Serang, Indonesia \\ 2 Jurusan Farmasi, Fakultas Sains Farmasi, Unma Banten, \\ Jl. Raya Labuan KM 23, 42278 Saketi, Pandeglang, Indonesia \\ ${ }^{3}$ Jurusan Biologi, Fakultas Sains Farmasi Unma Banten, \\ Jl. Raya Labuan KM 23, 42278 Saketi, Pandeglang, Indonesia \\ *Penulis Korespondensi,_Email:_fanosalam@gmail.com
}

\begin{abstract}
ABSTRAK
Bakteri Staphylococcus aureus adalah bakteri bulat yang berbentuk kokus, dan termasuk Grampositif. Bakteri ini bisa ditemukan pada kulit, alat kelamin, rongga hidung, mulut dan sekitar anus. Salah satu produk farmasi yang dapat menjaga kesehatan kulit dan melindungi kulit diantaranya ialah sabun. Daun mengkudu (M. citrifolia L.) mengandung berbagai senyawa seperti flavonoid, tanin, saponin, alkaloid, dan triterpenoid yang mampu sebagai antibakteri. Penelitian ini bertujuan untuk membuat formulasi sabun cair dari ekstrak daun M. citrifolia L. dan aktivitasnya sebagai antibakteri pada $S$ aureus. Daun $M$. citrifolia L. Diekstraksi menggunakan pelarut etanol $96 \%$ dengan metode maserasi sampai didapatkan ekstrak kental. Formulasi sabun dibuat dengan konsentrasi $20 \%$ 40\% dan 60\%. Evaluasi kualitas sabun meliputi uji organoleptik, uji tinggi busa dan uji $\mathrm{pH}$. Metode pada pengujian antibakteri dilakukan secara in vitro dengan cara difusi sumuran. Hasil pada uji kualitas formulasi sabun cair menunjukkan bahwa $\mathrm{pH}$ dan tinggi busa memiliki hasil yang baik dan telah memenuhi standar SNI 1996. Dari hasil penelitian menunjukan bahwa formulasi III dengan kadar ekstrak $60 \%$ memiliki aktivitas antimikroba yang besar dengan nilai 16,83 mm di kategorikan kuat.. Pada kontrol positif (Dettol) 60\% aktivitas antimikroba menunjukkan nilai sebesar 14,83 mm. Hasil uji statistika dilakukan dengan analisa One-Way ANOVA yang dilanjutkan dengan analisis LSD test Post hoc, sabun cair ekstrak M. citrifolia L. memiliki potensi antimikroba lebih besar dibandingkan dengan kontrol positif (Dettol).

Kata Kunci:

Kulit, Staphylococcus aureus, Morinda citrifolia L., Antibakteri, Sabun cair.

$\begin{array}{ccc}\text { Diterima: } & \text { Disetujui: } & \text { Online: } \\ \text { 12-07-2020 } & 2-09-2020 & 4-09-2020\end{array}$
\end{abstract}

\section{ABSTRACT}

The bacteria Staphylococcus aureus are round bacteria that are shaped like a cocci, and are Grampositive. These bacteria can be found on the skin, genitals, nasal cavity, mouth and around the anus. One of the pharmaceutical products that can maintain skin health and protect the skin is soap. The leaves of noni (M. citrifolia L.) contain various compounds such as flavonoids, tannins, saponins, alkaloids, and triterpenoids which are capable of being antibacterial. This study aims to make a liquid soap formulation from $M$. citrifolia L. leaf extract and its activity as an antibacterial to $S$ aureus. The leaves of $M$. citrifolia $L$. were extracted using $96 \%$ ethanol solvent by maceration method until a thick extract was obtained. Soap formulations are made with a concentration of $20 \% 40 \%$ and $60 \%$. Evaluation of soap quality includes organoleptic test, high foam test and $\mathrm{pH}$ test. The method of antibacterial testing 
is carried out in vitro by means of well diffusion. The results on the quality test of the liquid soap formulation showed that the $\mathrm{pH}$ and height of the foam had good results and had met the SNI 1996 Standards. From the results showed that formulation III with an extract content of $60 \%$ had a large antimicrobial activity with a value of $16.83 \mathrm{~mm}$ which was categorized as strong. In positive control (Dettol) 60\% antimicrobial activity showed a value of $14.83 \mathrm{~mm}$. The results of statistical tests were carried out by One-Way ANOVA analysis followed by LSD analysis Post hoc, liquid soap extract of M. citrifolia L. had greater antimicrobial potential than the positive control (Dettol).

Keywords:

Staphylococcus aureus, Morinda citrifolia L., Antibacterial, Liquid soap

$\begin{array}{ccc}\text { Received: } & \text { Accepted: } & \text { Online: } \\ \text { 2020-07-12 } & 2020-09-2 & 2020-09-4\end{array}$

\section{Pendahuluan}

Beberapa negara termasuk indonesia masih menjadi negara dengan urutan teratas penyakit infeksi yang menyebabkan sakit dan kematian. Infeksi ini dapat merugikan berbagai aspek seperti kesehatan dan ekonomi baik secara individu maupun nasional. Banyak hal yang bisa menyebabkan infeksi ini berkembang, seperti melalui benda, binatang, udara maupun dari manusia ke manusia. Salah satu faktor yg menyebabkan infeksi adalah bakteri seperti Staphylococcus aureus. Bakteri ini bisa ditemukan pada kulit, alat kelamin, rongga hidung, mulut dan sekitar anus [1].

Staphylococcus aureus adalah bakteri yang berbentuk bulat, termasuk bakteri Grampositif, jika di lihat di bawah mikroskop seperti kelompok anggur [2]. S. aureus dapat menyebabkan infeksi seperti pada luka, bisul, impetigo, jerawat, dan infeksi yang lebih serius seperti meningitis, pneumonia, osteomielitis, mastitis, infeksi saluran kemih, endokarditis, sindroma syok toksik, dan infeksi nosokomial [3].

Tubuh memiliki pelindung yang berfungsi mencegah berbagai macam rangsangan luar dan kerusakan yaitu kulit, perlindungan ini terbentuk melalui mekanisme biologis, seperti terbentuknya pigmen melanin yang melindungi dari sinar matahari, pembentukan lapisan epidermis secara terus-menerus, memproduksi cairan keringat, sebagai pengatur suhu tubuh, sebagai indra perasa dan peraba, respirasi, dan perlindungan dari infeksi luar [4]. Salah satu produk yang dapat menjaga kesehatan kulit yakni sabun, sabun adalah sediaan hasil dari mekanisme reaksi antara basa kuat dengan asam lemah, yang berfungsi sebagai pembersih kulit dari berbagai macam bakteri dan kotoran. Melindungi kulit dari bakteri yang berbahaya karena memiliki formula yang khusus, sabun ini juga disebut dengan sabun antiseptik yang dapat membuat kulit bersih, sehat dan mempengaruhi sistem imun tubuh [5].

Tumbuhan yang dapat digunakan sebagai antibakteri salah satunya adalah daun mengkudu. Mengkudu memiliki kandungan kimia seperti saponin, alkaloid, tanin, flavonoid, triterpenoid, antrakuinon, karoten, zat besi, zat kapur, senyawa moridin, aligerin-d-methyleter, xeronin, soranyideal, proxeronin, antioksidan, vitamin C, vitamin aA, askorbin, moridon, protein, lemak, kalori, niamin, karbohidrat, riboflavin, thiamin, mineral (kalsium, kalium, zat besi, natrium) [6,7].

Berdasarkan Penelitian sebelumnya, menyebutkan ekstrak etanol daun mengkudu efektif dalam menghambat bakteri $S$. aureus berada pada zona $(6-10 \mathrm{~mm})$, dan dikategorikan sedang [8]. Dan pada penelitian lainnya, kombinasi ekstrak daun 
mengkudu $30 \%$ dan bawang putih $10 \%$ mampu menghambat pertumbuhan S. aureus dengan zona hambat optimal seluas $12 \mathrm{~mm}$ yang dikategorikan kuat [9]. Hal ini yang mendasari peneliti untuk mengkaji efektivitas antibakteri dari sediaan sabun cair ekstrak daun mengkudu terhadap S. aureus. Sabun cair antibakteri ekstrak daun mengkudu di harapkan dapat menghambat pertumbuhan bakteri $S$. aureus pada kulit Manusia.

\section{Metode}

\subsection{Bahan}

Daun mengkudu (M. citrifolia L.), isolat bakteri S. aureus, Etanol 96\%, kalium hidroksida, minyak kelapa, Natrium Carboksilmetil Celulosa, Sodium Lauryl Sulfate (SLS), Asam Stearat, Butyl Hidroksi Toluen (BHT), Gliserin, Metil Paraben, Pengaroma melon, Aquadest, NA (Nutrien Agar), Sabun Dettol, Nacl 0,9\%, HCl, Pereaksi Mayer, Pereaksi Wagner, Metanol, Pita Mg, kloroform, $\mathrm{FeCl}_{3}$, Asam Asetat Anhidrat, $\mathrm{H}_{2} \mathrm{SO}_{4}, \mathrm{BaCl}_{2} \cdot 2 \mathrm{H}_{2} \mathrm{O}$.

\subsection{Pembuatan Ekstrak Etanol M. citrifolia L.}

Metode yang digunakan pada proses ekstraksi ini adalah maserasi. Dilakukan selama 3 hari dengan perbandingan 1:8. Serbuk simplisia sebanyak $1000 \mathrm{~g}$ dimasukan kedalam bejana ditambahkan pelarut etanol $96 \%$ sebanyak 3 liter sampai serbuk simplisia seluruhnya mampu terendam. Diamkan selama 1 × 24 jam, sambil beberapa kali diaduk. Setelah 24 jam, filtrat di saring dan ditampung. Proses remaserasi dilakukan dengan prosedur yang sama pada hari ke dua dengan pelarut 3 liter, dan hari ke tiga sebanyak 2 liter, dengan lama perendaman masing-masing 24 jam. Hasil maserasi dalam beberapa hari di saring, dan di ambil filtratnya lalu disatukan. Pisahkan pelarut dengan zat aktif menggunakan alat rotary evaporator dengan suhu $45-50^{\circ} \mathrm{C}$ sehingga di hasilkan ekstrak kental [10].

\subsection{Formulasi Sabun Cair Ekstrak Daun Mengkudu}

Formulasi sabun cair dibuat dalam tiga konsentrasi yakni konsentrasi $20 \%$, konsentrasi $40 \%$ dan konsentrasi $60 \%$ yang dapat dilihat pada tabel 2 .

Tabel 1. Formulasi sediaan sabun cair konsentrasi 20\%,40\% dan 60\%

\begin{tabular}{|c|c|c|c|c|c|c|}
\hline Bahan & Satuan & $\begin{array}{c}\text { Formula } \\
\text { I } \\
0 \%\end{array}$ & $\begin{array}{c}\text { Formula } \\
\text { II } \\
20 \%\end{array}$ & $\begin{array}{c}\text { Formula } \\
\text { III } \\
40 \%\end{array}$ & $\begin{array}{c}\text { Formula } \\
\text { IV } \\
60 \%\end{array}$ & Fungsi \\
\hline $\begin{array}{c}\text { Ekstrak } \\
\text { daun }\end{array}$ & $\mathrm{g}$ & 0 & 20 & 40 & 60 & Zat Aktif \\
\hline Mengkudu & & & & & & \\
\hline $\begin{array}{c}\text { Minyak } \\
\text { kelapa }\end{array}$ & $\mathrm{mL}$ & 6 & 6 & 6 & 6 & $\begin{array}{c}\text { Fase } \\
\text { Minyak }\end{array}$ \\
\hline KOH & $\mathrm{mL}$ & 1,5 & 1,5 & 1,5 & 1,5 & Pengemulsi \\
\hline Na-CMC & $\mathrm{g}$ & 1 & 1 & 1 & 1 & Zat Pengisi \\
\hline SLS & $\mathrm{g}$ & 2,5 & 2,5 & 2,5 & 2,5 & $\begin{array}{c}\text { Pembentuk } \\
\text { Busa }\end{array}$ \\
\hline $\begin{array}{c}\text { Asam } \\
\text { Stearat }\end{array}$ & $\mathrm{g}$ & 2 & 2 & 2 & 2 & Pengemulsi \\
\hline BHT & $\mathrm{g}$ & 1 & 1 & 1 & 1 & Antioksidan \\
\hline Pengaroma & $\mathrm{mL}$ & 1 & 1 & 1 & 1 & Pengaroma \\
\hline $\begin{array}{c}\text { Metil } \\
\text { Paraben }\end{array}$ & $\mathrm{g}$ & 0,25 & 0,25 & 0,25 & 0,25 & Pengawet \\
\hline Gliserin & $\mathrm{mL}$ & 5 & 5 & 5 & 5 & Emolien \\
\hline
\end{tabular}




\begin{tabular}{lllllll}
\hline Aquadest & $\mathrm{mL}$ & ad 100 & ad 100 & ad 100 & ad 100 & Pelarut \\
\hline
\end{tabular}

\subsection{Uji Aktivitas Anti bakteri Sediaan Sabun Cair}

Formulasi Penentuan aktivitas antibakteri S. aureus dilakukan dengan cara in vitro menggunakan metode difusi sumuran. Dengan Prosedur: Pembuatan Standar Kekeruhan Larutan (Mc. Farland), tujuannya dipakai sebagai standar kekeruhan suspensi bakteri uji. Larutan $\mathrm{H}_{2} \mathrm{SO}_{4}$ 0,36 $\mathrm{N}$ sebanyak 9,5 ml dicampurkan dengan larutan $\mathrm{BaCl}_{2} \cdot 2 \mathrm{H}_{2} \mathrm{O} 1,175 \%$ sebanyak $0,5 \mathrm{ml}$ dalam erlenmeyer. Kemudian dikocok sampai terbentuk larutan yang keruh. Bakteri uji yang sudah di larutkan dan di bandingkan dengan Mc Farland di inokulasikan ke dalam cawan, lalu di buat lubang sumuran dengan pencadangan atau alat lubang dengan diameter $6 \mathrm{~mm}$, pada media agar yang sudah padat, Diberi tanda pada masing-masing lubang sumuran dengan masingmasing konsentrasi serta kontrol positif dan negatif, Setelah diberi tanda masukkan formulasi sabun mandi cair kedalam lubang sumuran pada masing-masing konsentrasi sebanyak 0,05 ml, Diinkubasi kedalam alat inkubator dengan suhu $37^{\circ} \mathrm{C}$ selama waktu 24 jam, lalu perhatikan zona bening yang terbentuk di sekitar lubang, dan ukur diameter tersebut dengan menggunakan mistar [11].

\subsection{Evaluasi Sabun Cair ekstrak M. Citrifolia L.}

a. Uji Organoleptik

Pengamatan organoleptis meliputi uji dengan memeriksa bentuk, warna dan aroma yang dilakukan secara makroskopis. [12].

b. Uji pH

Pengukuran $\mathrm{pH}$ sabun cair ekstrak daun mengkudu dilakukan menggunakan kertas $\mathrm{pH}$ Universal. $1 \mathrm{~mL}$ sabun cair ditambahkan akuades sampai $10 \mathrm{~mL}$ kemudian celupkan kertas $\mathrm{pH}$ ke dalam sabun cair selama beberapa saat kemudian angkat dan cocokan dengan warna indikator. [12].

c. Uji Tinggi Busa

Timbang sampel sebanyak $1 \mathrm{~g}$, masukkan ke dalam tabung reaksi, lalu tambahkan akuades sampai $10 \mathrm{~mL}$, kocok tabung reaksi dengan cara membolak-balikkan tabung, kemudian diukur tinggi busa yang didapatkan. Lalu diamkan tabung selama 5 menit, dan ukur kembali tinggi busa yang didapatkan setelah 5 menit. Persyaratan tinggi busa pada sediaan dikatakan memenuhi standar apabila berada pada range 1,3-22 cm [13].

2.6. Analisis Data

Data hasil perhitungan Zona hambat bakteri dengan konsentrasi 20\%, 40\%, 60\%, Kontrol negatif dan Kontrol positif dilakukan uji normalitas Shapiro-Wilk untuk mengetahui terdistribusi normal atau tidak pada masing-masing data kelompok dengan nilai $(\mathrm{p}>0,05)$. Uji lanjutan setelah data terdistribusi normal adalah Analisis One Way ANOVA dengan tingkat kemaknaan $(\mathrm{p}<0,05)$ untuk melihat efek antibakteri pada semua kelompok perlakuan. Digunakan Uji One Way ANOVA untuk data populasi atau sampel yang akan diuji normal dengan nilai signifikan yang diperoleh harus lebih kecil dari 0,05, kemudian dilanjutkan dengan uji LSD (Least Significant Different) untuk mengetahui di kelopok mana yang terdapat perbedaan bermakna.

\section{Hasil dan Pembahasan}

\subsection{Ekstraksi}

Ekstraksi adalah proses pemisahan sampel dari campurannya dengan menggunakan pelarut yang sesuai. Penggunaan etanol 96\% sebagai pelarut karena etanol selektif 
terhadap senyawa-senyawa tertentu, stabil secara kimia dan fisika, relatif aman sesuai dengan syarat pelarut yang baik untuk ekstraksi, dapat melarutkan senyawa polar maupun nonpolar, dan dapat memperbaiki stabilitas senyawa terlarut [14]. Berikut data bobot proses ekstaksi :

Tabel 2. Bobot Ekstrak M. citrifolia L

\begin{tabular}{lcc}
\hline No & Sampel & Berat \\
\hline 1 & Simplisia Basah & 20.000 gram \\
2 & Simplisia Kering & 2.900 gram \\
3 & Ekstrak Kental & 279 gram \\
4 & Rendemen & $9 \%$ \\
\hline
\end{tabular}

Hasil simplisia daun mengkudu yang telah diekstraksi didapatkan ektrak kental sebanyak 279 gram dengan warna hijau pekat, dengan rendemen ekstrak sebesar $9 \%$. hasil menunjukan bahwa rendemen ekstrak tidak memenuhi syarat yaitu kurang dari $17,9 \%$. Berdasarkan hasil rendemen dapat diasumsikan bahwa komponen bioaktif yang terkandung dalam daun mengkudu hanya sedikit, atau Kurangnya rendemen yang dihasilkan kemungkinan karena proses penarikan senyawa yang kurang maksimal akibat waktu yang digunakan cukup singkat, [15].

3.2. Uji Aktivitas Antibakteri Sediaan Sabun Cair

Pengujian aktivitas antimikroba dilakukan secara in vitro menggunakan metode difusi sumuran. Pemilihan menggunakan metode sumuran karena dilihat dari sediaan sabun yang kental sehingga lebih memungkinkan pengujian aktivitas antimikroba menggunakan metode tersebut. Kelebihan metode sumuran yaitu lebih mudah menghitung dan mengukur luas zona bening yang terbentuk disekitar sumuran, sebab isolat bakteri beraktivitas sampai kebagian bawah media NA (nutrien agar) [11]. Aktivitas antibakteri dikategorikan berdasarkan diameter zona hambat, yakni: zona hambat kurang dari $5 \mathrm{~mm}$ di kategorikan lemah, zona hambat 5-10 $\mathrm{mm}$ di kategorikan sedang, zona hambat 11-20 mm di kategorikan kuat, dan zona hambat lebih dari $20 \mathrm{~mm}$ di kategorikan sangat kuat [7].

Dari data yang dihasilkan dapat dilihat bahwa sabun cair ekstrak M. citrifolia L. dengan konsentrasi $20 \%$ memiliki potensi antimikroba sebesar 8,66 mm dikategorikan sedang, konsentrasi 40\% 13,16 mm dikategorikan kuat, dan konsentrasi 60\% 16,83 mm dikategorikan kuat, Untuk kontrol positif (Dettol) 60\% memiliki potensi antimikroba sebesar 14,83 mm dikategorikan kuat, kontrol negatif (Basis sabun) tidak memiliki potensi antimikroba hal ini di tandai dengan tidak ada zona bening di sekitar sumuran. Zona hambat yang dihasilkan pada konsentrasi $60 \%$ memiliki aktivitas antimikroba yang kuat dan lebih besar dari semua formulasi, dan lebih tinggi dari kontrol positif ${ }^{*}$ Dettol. Pemilihan kontrol positif Dettol dengan konsetrasi $60 \%$ dikarenakan sabun dettol cukup familiar dan banyak peminatnya dipasaran dan mengandung zat aktif Chloroxylenol yang di percaya sebagai antibakteri. Berikut ditampilkan hasil uji aktivitas antibakteri : 


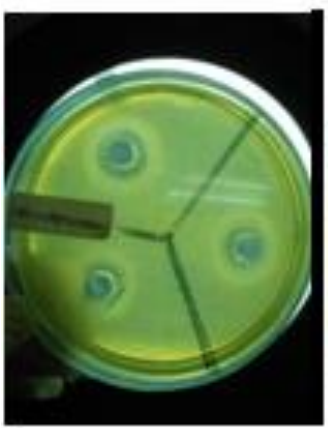

(A)

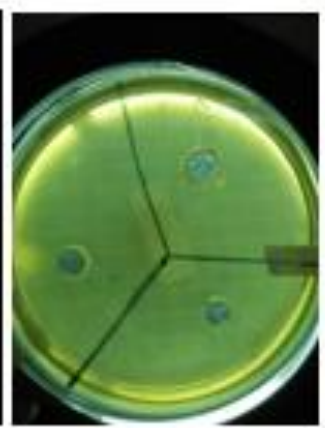

(B)

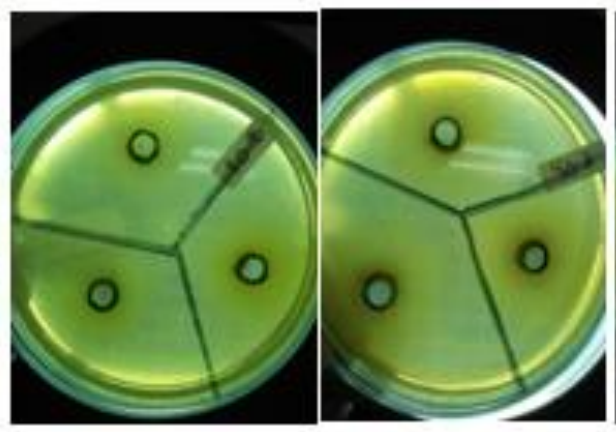

(C)

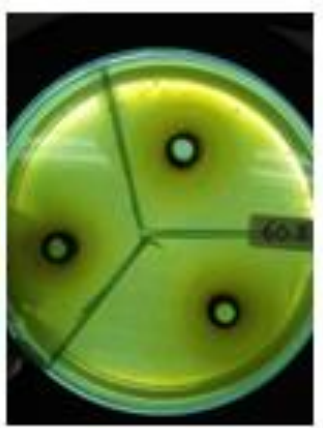

(E)

Keterangan:

(A) : Kontrol positif (Dettol)

(B) : Kontrol negatif (Basis sabun)

(C) : Formulasi sabun cair konsentasi $20 \%$

(D) : Formulasi sabun cair konsentrasi $40 \%$

(E) : Formulasi sabun cair konsentrasi 60\%

Gambar 1. Hasil Uji Diameter Zona Hambat Bakteri

Berdasarkan zona bening yang terbentuk, Sabun cair ekstrak daun mengkudu mampu menghambat pertumbuhan S. aureus.

3.3. Evaluasi sediaan Sabun Cair ekstrak M. Citrifolia L.

Evaluasi mutu sabun cair meliputi uji organoleptik, uji $\mathrm{pH}$, dan uji tinggi busa yang dilakukan pada minggu ke-0 sampai minggu ke-4. Berikut ditampilkan data hasil evaluasi sediaan sabun cair ekstrak $M$. citrifolia L. :

Tabel 3. Hasil Evaluasi Organoleptis Sabun Cair Ekstrak M. citrifolia L.

\begin{tabular}{|c|c|c|c|c|c|c|}
\hline \multirow{2}{*}{ NO } & \multirow{2}{*}{ Formula } & \multirow{2}{*}{ Pemerian } & \multicolumn{4}{|c|}{ Pemeriksaan Minggu Ke- } \\
\hline & & & 1 & 2 & 3 & 4 \\
\hline \multirow[t]{3}{*}{1} & F0 & -Bentuk & cairan & cairan & cairan & Cairan \\
\hline & & -Warna & putih & putih & putih & putih \\
\hline & & -Aroma & wangi & wangi & wangi & wangi \\
\hline \multirow[t]{3}{*}{2} & F1 & -Bentuk & cairan & cairan & cairan & cairan \\
\hline & & -Warna & hitam & hitam & hitam & hitam \\
\hline & & -Aroma & wangi & wangi & wangi & wangi \\
\hline \multirow[t]{3}{*}{3} & F2 & -Bentuk & cairan & cairan & CK & CK \\
\hline & & -Warna & hitam & hitam & hitam & hitam \\
\hline & & -Aroma & wangi & wangi & wangi & wangi \\
\hline \multirow[t]{3}{*}{4} & F3 & -Bentuk & $\mathrm{CK}$ & $\mathrm{CK}$ & CK & CK \\
\hline & & -Warna & hitam & hitam & hitam & hitam \\
\hline & & -Aroma & wangi & wangi & wangi & wangi \\
\hline \multirow[t]{3}{*}{5} & Kontrol + & -Bentuk & cairan & cairan & cairan & cairan \\
\hline & & -Warna & B & B & B & B \\
\hline & & -Aroma & Wangi & wangi & Wangi & wangi \\
\hline
\end{tabular}

Keterangan : CK: cairan kental; B: bening; FO: kontrol negatif (basis); F1: konsentrasi 20\%; F2: konsentrasi 40\%; F3: konsentrasi 60\%; kontrol +: sabun dettol. 
Tabel 4. Hasil Pengujian $\mathrm{pH}$ sabun cair ekstrak M. citrifolia L

\begin{tabular}{lllcccc}
\hline \multirow{2}{*}{ No } & Formula & \multicolumn{5}{c}{$\mathbf{p H}$} \\
Minggu Ke- & \multirow{2}{*}{ Standar } \\
\cline { 3 - 6 } & & $\mathbf{1}$ & $\mathbf{2}$ & $\mathbf{3}$ & $\mathbf{4}$ & \\
\hline 1 & F0 & 10 & 10 & 10 & 10 & $8-11$ \\
2 & F1 & 10 & 10 & 10 & 10 & {$[17]$} \\
3 & F2 & 10 & 10 & 10 & 10 & \\
4 & F3 & 10 & 10 & 10 & 10 & \\
5 & Kontrol + & 9 & 9 & 9 & 9 & \\
\hline
\end{tabular}

Keterangan : F0 : Kontrol negatif (Basis); F1 : Konsentrasi 20\%; F2 : Konsentrasi 40\%;

F3; Konsentrasi 60\%; kontrol + : Sabun Dettol ${ }^{*}$

Tabel 5. Hasil Pengujian Tinggi Busa Sabun Cair Ekstrak M. citrifolia L.

\begin{tabular}{|c|c|c|c|c|c|c|}
\hline \multirow{3}{*}{ No } & \multirow{3}{*}{ Formula } & \multicolumn{4}{|c|}{ Tinggi Busa } & \multirow{3}{*}{ Standar } \\
\hline & & \multicolumn{4}{|c|}{ Minggu Ke- } & \\
\hline & & 1 & 2 & 3 & 4 & \\
\hline 1 & F0 & $2 \mathrm{~cm}$ & $2 \mathrm{~cm}$ & $2 \mathrm{~cm}$ & $2 \mathrm{~cm}$ & $1,3-22 \mathrm{~cm}$ \\
\hline 2 & $\mathrm{~F} 1$ & $2 \mathrm{~cm}$ & $2 \mathrm{~cm}$ & $2 \mathrm{~cm}$ & $2 \mathrm{~cm}$ & [17] \\
\hline 3 & F2 & $1,5 \mathrm{~cm}$ & $1,5 \mathrm{~cm}$ & $1,5 \mathrm{~cm}$ & $1,5 \mathrm{~cm}$ & \\
\hline 4 & F3 & $1,5 \mathrm{~cm}$ & $1,5 \mathrm{~cm}$ & $1,5 \mathrm{~cm}$ & $1,5 \mathrm{~cm}$ & \\
\hline 5 & Kontrol + & $2 \mathrm{~cm}$ & $2 \mathrm{~cm}$ & $2 \mathrm{~cm}$ & $2 \mathrm{~cm}$ & \\
\hline
\end{tabular}

Keterangan : M: Minggu; F0 : Kontrol negatif (Basis); F1 : Konsentrasi 20\%; F2 : Konsentrasi 40\%; F3 : Konsentrasi 60\%; Kontrol + : Sabun Dettol ${ }^{*}$

Hasil uji organolpetis menunjukan, sediaan berbentuk cairan dan cairan kental sesuai konsentrasi sabun cair, sabun berwarna hitam, dan aromanya wangi karena di tambahkan pengaroma pada saat formulasi. Tidak ada perubahan warna dan aroma selama 4 minggu, hanya perubahan bentuk menjadi sedikit kental, hal ini di karenakan terdapat $\mathrm{Na}-\mathrm{CmC}$ pada formulasi yang digunakan sebagai zat pengisi yang dapat mengikat air didalamnya [16].

Hasil uji $\mathrm{pH}$ menunjukkan bahwa pada setiap formulasi memiliki nilai $\mathrm{pH}$ yang tidak jauh berbeda. Untuk kontrol negatif menunjukan $\mathrm{pH}$ 10, formulasi 20\%, 40\% dan $60 \%$ menunjukan $\mathrm{pH} 10$, dan kontrol positif menunjukan $\mathrm{pH}$ 9. yang artinya untuk formulasi sabun cair ekstrak M. citrifolia L. yang di buat memiliki pH yang sesuai dengan syarat ketentuan pH dalam pembuatan sabun cair yakni 8 - 11 (SNI 06-4085-1996). Pengujian dilakukan selama 4 minggu, tidak ada perubahan pada pengujian $\mathrm{pH}$ sabun cair, hal ini terjadi dikarenakan bahan $\mathrm{KOH}$ yang digunakan masih didalam batas syarat sehingga tidak mempengaruhi pada $\mathrm{pH}$ sediaan.

Pengujian tinggi busa bertujuan untuk mengetahui kemampuan sabun untuk menghasilkan busa. Persyaratan tinggi busa sabun cair yakni 1,3-22 cm [17]. Dari hasil pengamatan menunjukan bahwa kontrol positif (Dettol) menghasilkan busa setinggi 2 $\mathrm{cm}$, kontrol negatif setinggi $2 \mathrm{~cm}$, konsentrasi 20\% setinggi 1,5 cm, konsentrasi 40\% 1,5 $\mathrm{cm}$ dan konsentrasi $60 \%$ setinggi $2 \mathrm{~cm}$. Hal ini menandakan sabun cair ekstrak daun mengkudu telah memenuhi syarat. Pengujian tinggi busa dilakukan selama 4 minggu 
tidak ada perubahan pada pengujian, tinggi busa relatif sama dari minggu pertama sampai minggu keempat.

\subsection{Analisis Data Statistik Diameter Zona Hambat Antibakteri}

Analisis statistika hasil uji Normalitas (Shapiro-Wilk) menunjukan diameter zona hambat bakteri formulasi sabun cair ekstrak $M$. citrifolia L. hasil sampel normal $(p>0,05)$ dengan signifikasi 0.68. Dan Uji Homogenitas (Levene) menunjukan diameter zona hambat bakteri formulasi sabun cair ekstrak $M$. citrifolia L. bervariasi secara homogen $(p>0,05)$ dengan nilai signifikan 1,000. Apabila pada uji homogenitas dan normalitas sudah memenuhi syarat, maka analisis diteruskan dengan uji One-way ANOVA. Uji analisa One-way ANOVA menghasilkan nilai yang berbeda signifikan atau tidak identik $(\mathrm{p}<0,05)$. Kemudian uji analisa dilanjutkan dengan Post hoc test (LSD). Uji ini merupakan uji yang dilakukan apabila nilai rata-rata dari masing-masing kelompok terdapat perbedaan, fungsinya untuk mengetahui yang berbeda terdapat pada kelompok mana saja. Hasil analisa post hoc dapat disimpulkan jika pada masing-masing populasi sampel tidak identik atau ada sebuah perbedaan yang memiliki makna dengan hasil uji statistik $(\mathrm{p}<0,05)$.

\section{Kesimpulan}

Berdasarkan hasil penelitian maka dapat disimpulkan bahwa Sabun cair dari ekstrak $M$. citrifolia L. memiliki efektivitas dalam menghambat bakteri S. aureus. yakni pada konsentrasi formula $20 \%$ menghasilkan diameter zona hambat sekitar 8,66 mm, pada konsentrasi formula 40\% menghasilkan diameter zona hambat sekitar 13,16 mm dan pada konsentrasi $60 \%$ menghasilkan diameter hambat sebesar $16,83 \mathrm{~mm}$. zona hambat optimal berada pada konsentrasi tertinggi yakni 60\% dengan kategori kuat dalam menghambat pertumbuhan bakteri. Hasil pembuatan sabun menunjukan bahwa daun mengkudu dapat di formulasikan menjadi sabun cair antibakteri dan uji kualitas sediaan sabun cair ekstrak $M$. citrifolia L. menunjukkan bahwa sediaan sabun cair memiliki kadar $\mathrm{pH}$ dan tinggi busa yang telah memenuhi standar. Dan tidak ada perubahan signifikan selama pengamatan 4 minggu. Sehingga formulasi dapat digunakan sebagai alternatif untuk menghambat pertumbuhan bakteri pada kulit. Peneliti selanjutnya dapat mengembangkan kualitas mutu sabun cair seperti melakukan pengujian bobot jenis, cemaran mikroba, dan alkali bebas.

\section{Referensi}

[1]. Triana, D., 2017. Frekuensi $\beta$-Lactamase Hasil Staphylococcus aureus Secara Iodometri di Laboratorium Mikrobiologi Fakultas Kedokteran Universitas Andalas. Jurnal Gradien, 10 ( 2) : 992-995

[2]. Tyaningsih, dkk., 2010. Buku Ajar Penyakit Infeksius I. Airlangga University Press: Surabaya.

[3]. Nismawati., R., Sjahril, R., \& Agus, R., 2018. Deteksi Methicillin Resistant Staphylococcus aureus (MRSA) Pada Pasien Rumah Sakit Universitas Hasanuddin Dengan Metode Kultur. Jurusan Biologi, UIN Alaudin Makasar, 1521. ISBN: 978-602-72245-3-7. doi: https://doi.org/10.24252/psb.v4i1.5932

[4]. Kasenda, J. C., YamLean, P. V. Y., \& Lolo, W. A., 2016. Formulasi dan Pengujian Aktivitas Antibakteri Sabun Cair Ekstrak Etanol Daun Ekor Kucing (Acalypha 
hispida Burm. F) Terhadap Pertumbuhan Bakteri Staphylococcus aureus. Jurnal Ilmiah Farmasi 5 (3) : 40-47. doi: https://doi.org/10.35799/pha.5.2016.12936

[5]. Dimpudus, S. A., Yamlean, P. V. Y., \& Yudistira, A. 2017. Formulasi Sediaan Sabun Cair Antiseptik Ekstrak Etanol Bunga Pacar Air (Impatiens balsamina L.) dan Uji Efektivitasnya Terhadap Bakteri Staphylococcus aureus Secara In Vitro. Jurnal Ilmiah Farmasi, 6 (3): 208-215. doi: https://doi.org/10.35799/pha.6.2017.16885.

[6]. Afiff, F. E., \& Amilah, S., 2017. Efektivitas Ekstrak Daun Mengkudu (Morinda citrifolia L.) dan Daun Sirih Merah (Piper Crocatum Ruiz \& Pav) Terhadap Zona Hambat Pertumbuhan Staphylococcus aureus. Journal of Science, 10 (1): 12-16. ISSN: $1412-1840$.

[7]. Simatupang, O. C., Abidjulu, J., \& Siagian, K. V., 2017. Uji daya hambat ekstrak daun mengkudu (Morinda citrifolia L.) terhadap pertumbuhan Candida albicans secara in vitro. Jurnal e-GiGi (eG), 5 (1) : 1-6. doi:https:// doi.org/10.35790/eg.5.1.2017.14701

[8]. Erina, dkk. 2019. Uji Daya Hambat Ekstrak Etanol Daun Mengkudu (Morinda citrifolia L.) Terhadap Pertumbuhan Staphylococcus aureus. Jurnal Kedokteran, $\begin{array}{llll}\text { Universitas } \quad \text { Kyiah } & \text { K(3):161-169. doi: }\end{array}$ https:// doi.org/10.21157/jim\%20vet..v3i3.11377

[9]. Lestari, I., \& Hanum, G. R., 2019. Aktivitas Antibakteri Kombinasi Ekstrak Daun Mengkudu (Morinda citrifolia L.) dan Bawang Putih (Allium sativum) terhadap Escherichia coli dan Staphylococcus aureus. Journal of Medical Laboratory Science Technology, 2 (2) : 43-47. doi: 10.21070/medicra.v2i2.1475

[10]. Herawati, A., \& Amelia, T. R. N., 2018. Potensi Bahan Herbal Ekstrak Etanol Daun Mengkudu Asal Desa Wajak Lor, Tulungagung, Jawa Timur Terhadap Bakteri Penyebab Jerawat. Jurnal JuKe 2 (2) : 173-178.

[11]. Misna, \& Diana, K., 2016. Aktivitas Antibakteri Ekstrak Kulit Bawang Merah (Allium Cepa L.) Terhadap Bakteri Staphylococcus aureus. Jurnal. Journal of pharmacy 2 (2) : 138-144. doi: 10.22487/j24428744.2016.v2.i2.5990

[12]. Handayani, F., Sundu, R., \& Sari, R. M., 2017. Formulasi dan Uji Aktivitas Antibakteri Streptococcus mutans Dari Sediaan Mouthwash Ekstrak Daun Jambu Biji (Psidium guajava L.). Jurnal Sains dan Kesehatan 1 (8) : 422-433. doi: https:// doi.org/10.25026/jsk.v1i8.62

[13]. Ferdinan, A., \& Sari, R., 2017. Pengujian Aktivitas Antibakteri Sabun Cair dari Ekstrak Kulit Daun Lidah Buaya. Pharm Sci Res, 4 (3): 11-120. doi: 10.7454/psr.v4i.3763

[14]. Harbone, J. B., 1996. Metode Fitokimia Penuntun cara Modern Menganalisis Tumbuhan, diterjemahkan oleh Kosasih P. \& Imam S. Edisi II, Hal 4-7: 69-76, ITB, Bandung.

[15]. Wijaya, H., Novitasari., \& Jubaidah, S., 2018. Perbandingan Metode Ekstraksi Terhadap Rendemen Ekstrak Daun Rambai Laut (Sonneratia caseolaris L. Engl). Jurnal Ilmiah Manuntung, 4(1) : 79-83. 
[16]. Naiu, A. S., \& Yusuf, N., 2018. Nilai Sensoris Dan Viskositas Skin Cream Menggunakan Gelatin Tulang Tuna Sebagai Pengemulsi Dan Humektan. Jurnal PHPI, 21 (2): 199-207. doi: https://doi.org/10.17844/jphpi.v21i2.22838

[17]. SNI 06-4085-1996, Standar Mutu Sabun Mandi Cair, Dewan Standarisasi Nasional : Jakarta. 